\title{
A ARBITRAGEM E AS PARCERIAS PÚBLICO-PRIVADAS*
}

\author{
GUSTAVO HENRIQUE JUSTINO DE OLIVEIRA**
}

1. Contextualização. 2. Uma nova contratualização administrativa: rumo à paridade nas relações contratuais? 3. a arbitragem no direito brasileiro. 4. Conciliando a arbitragem com as parcerias público-privadas. 5. Considerações finais.

\section{Contextualização}

Propõe-se no presente trabalho defender a possibilidade de utilização do juízo arbitral para a solução de litígios e controvérsias originados de relações jurídicas de natureza contratual estabelecidas entre a Administração pública e os particulares, com ênfase nos contratos de parceria público-privada.

O tema é instigante, e mereceu a atenção de inúmeros autores pátrios.' ${ }^{\prime}$ No entanto, não seria correto afirmar que o entendimento favorável ao emprego da via arbitral para o deslinde das questões assinaladas é generalizado.

* À advogada Marcela Roza Leonardo Zen e às acadêmicas Ana Carolina Hohmann (UFPR) e Manuella Lucia Zanini Fadel (UTP) o agradecimento do autor pela diligente e prestimosa colaboração para a realização desse artigo.

** Doutor em Direito do Estado pela USP. Procurador do Estado do Paraná. Advogado e Consultor em Curitiba.

1 Cf. BARBOSA, Joaquim Simões; SOUZA, Carlos Affonso Pereira de. Arbitragem nos contratos administrativos: panorama de uma discussão a ser resolvida. In: ALMEIDA, Ricardo Ramalho. Arbitragem interna e internacional: questões de doutrina e prática. Rio de Janeiro: Renovar, 2003. p. 267-291; DALLARI, Adilson Abreu. Arbitragem na concessão de serviço público. Revista de Informação Legislativa, Brasília, a. 32, n. 128, p. 63-67, out./dez. 1995; GRAU, Eros Roberto. Arbitragem e contrato administrativo. Revista Trimestral de Direito Público, São Paulo, n. 32, p. 14-20, 2000; GRINOVER, Ada Pellegrini. Arbitragem e prestação de serviços públicos. Revista de Direito Administrativo, Rio de Janeiro, n. 233, p. 377-385, jul./set. 2003; GUERREIRO, José Alexandre Tavares. Arbitragem nos contratos com o Estado: direito brasileiro e direito comparado. SEMINÁRIO INTERNACIONAL SOBRE DIREITO ARBITRAL. 1., 2003, Belo Horizonte [Trabalhos apresentados], Belo Horizonte: Câmara de Arbitragem de Minas Gerais, 2003. p. 294-304; LIMA, Cláudio Vianna de. A lei de arbitragem e o art. 23, XV da Lei de Concessões. Revista de

R. Dir. Adm.,

Rio de Janeiro, 241: 241-271, Jul./Set. 2005 
Em decisões do Tribunal de Contas da União ${ }^{2}$ e na jurisprudência de nossas Cortes Judiciárias comprova-se o grau de divergência que a matéria vem suscitando, embora seja possível destacar uma certa evolução do seu tratamenta, a exemplo do recente acórdão lavrado pelo Tribunal de Alçada do Estado do Paraná na Apelação Cível n. 247.646-0. ${ }^{3}$

$\mathrm{Na}$ legislação brasileira visualiza-se uma tendência para a autorização da arbitragem em situações peculiares, sobretudo envolvendo determinados setores regulados por leis específicas (v.g. serviços de telecomunicação, inc. XV do art. 93 da Lei federal n. 9.472/97; exploração e produção de petróleo e gás natural, inc. $X$ do art. 43 da Lei federal n. 9.478/97).

Entretanto, ainda que argumentos favoráveis e desfavoráveis arrolados na doutrina e nas jurisprudências administrativa e judiciária sejam aqui e ali reprisados, pretende-se na presente oportunidade entabular uma discussão sobre a viabilidade do juízo arbitral em contratos que retratam uma perspectiva evolucionista da Administração pública: a Administração pública paritária. ${ }^{4}$

Conforme aduzem Eduardo GARCÍA DE ENTERRÍA e Tomás-Ramón FERNÁNDEZ, não é possível ignorar que hodiernamente a "Administração negocia e que a negociação converteu-se em um instrumento imprescindível para a tarefa de administrar". 5

Sob a ótica dessa nova forma de administrar, Sabino CASSESE prega a necessidade da reciprocidade de concessões entre a Administração pública e particulares, situações geradores de icordos administrativos. Segundo o autor, o enfoque da negociação significa que Administração pública, empresas, organizações não-gover-

Direito Administrativo, Rio de Janeiro, n. 209, p. 91-104, jul./set. 1997; MATTOS, Mauro Roberto Gomes. Contrato administrativo e a lei de arbitragem. Revista de Direito Administrativo, Rio de Janeiro, n. 223, p. 115-131, jan./mar. 2001; MEDEIROS, Suzana Domingues. Arbitragem envolvendo o Estado no direito brasileiro. Revista de Direito Administrativo, Rio de Janeiro, n. 233, p. 71-101, jul./set. 2003; MOREIRA NETO, Diogo de Figueiredo. Arbitragem nos contratos administrativos. Revista de Direito Administrativo, Rio de Janeiro, n. 209, p. 81-90, jul./set. 1997; MOTTA, Carlos Pinto Coelho. Arbitragem nos contratos administrativos. Boletim de Direito Administrativo, São Paulo, v. 13, n. 10, p. 672-676, out. 1997; SZKLAROWSKY, Leon Frejda. Arbitragem e os contratos administrativos. Revista de Direito Administrativo, Rio de Janeiro, $n$. 209, p. 105-107, jul./set. 1997; TÁCITO, Caio. Arbitragem nos litígios administrativos. Revista de Direito Administrativo, Rio de Janeiro, n. 210, p. 111-115, out./dez. 1997; TIBURCIO, Carmen. A lei de arbitragem e a pretensa inconstitucionalidade de seu artigo $7^{\circ}$. Revista de Direito Admi. nistrativo, Rio de Janeiro, n. 218, p. 175-196, out./dez. 1999.

2 Não há um entendimento uniforme firmado no âmbito do Tribunal de Contas da União com relação ao tema, embora a tendência revelada seja desfavorável à arbitragem nos contratos firmados pela Administração. Nesse sentido, cf. uma das decisões mais recentes, Acórdão n. 584/2003, da 2. Câmara do TCU, j. em 10.04 2003, p. no DOU de 28.04.2003.

3 Acórdão n 18.014, julgado em 11.02.2004, publicado no DJE n. 6.565, de 20.02.20004.

4 Na doutrina italiana há estudos acerca de um direito administrativo paritário. Cf. MASUCCI, Alfonso. Trasformazione dell'amministrazione e moduli convenzionali: il contratto di diritto pubblico. Napoli: Jovene, 1988, p. 65-67.

5 FERNÁNDEZ, Tomás-Ramón, GARCÍA DE ENTERRÍA, Eduardo. Curso de derecho administrativo. 9. ed. Madrid: Civitas, 1999, v. 1, p. 663. 
namentais e cidadãos natural e mutuamente cedem sobre pontos relativos ao objeto em discussão, favorecendo a obtenção de um equilíbrio de interesses originalmente contrapostos, os quais permaneceriam contrapostos se não fosse pela ocorrência de trocas e concessões entre as partes. ${ }^{6}$

Eis uma das principais consequências da intensificação das relações e do estreitamento dos laços entre Estado, empresas e organizações da sociedade civil no mundo contemporâneo. O caminho da negociação - e não o percurso da imposição para a composição de eventuais dissensos entre as partes, pressupõe o reconhecimento (ainda que relativizado pelo regime jurídico-administrativo) da autonomia das partes envolvidas.

Com isso, a verticalização entre a Administração pública e o particular nas relações contratualizadas é - em algumas hipóteses - fortemente atenuada ou mesmo afastada. É que em um cenário em que vigora a necessidade da realização de parcerias, $^{7}$ não há como sustentar uma relação de total subordinação entre a Administração e as entidades parceiras.

A partir desse contexto Gaspar ARIÑO ORTIZ alude à existência de um Estado contratual, em que a crescente utilização de instrumentos negociais firmados entre o Estado e as organizações privadas (providas ou destituídas de finalidades lucrativas), como modo de atingir os fins públicos, passa a prevalecer sobre antigas práticas que privilegiavam a noção de autoridade e da imposição unilateral das decisões tomadas pelo Estado. ${ }^{8}$

Por via reflexa, vem surgindo um novo direito administrativo, mais participativo, fruto da gradual compatibilização da lógica da imposição e da unilateralidade com a lógica da negociação e da multilateralidade.

Conforme atesta José Casalta NABAIS, "a ideia de que o direito público, nas relações entre o indivíduo e o Estado, tem como campo de aplicação os actos de autoridade (actos em que o Estado manifesta o seu imperium e impõe a sua autoridade ao administrado) está, desde há muito tempo, ultrapassada". 9 Alude-se à expressão Administração concertada, "em que a Administração renunciaria ao emprego de

6 CASSESE, Sabino. La arena pública: nuevos paradigmas para el Estado. In: La crisis

del Estado. Buenos Aires: Abeledo Perrot, 200s. p. 101-160.

7 Importa destacar que o caráter polissêmico do termo parceria é manifesto. Sem embargo, concorda-se com Jean-Pierre GAUDIN, autor que alude à idéia de parceria para genericamente representar as "convenções múltiplas que ligam os poderes públicos, o setor privado e, outras vezes, o que denomina-se associaçð̋es da "sociedade civil"". GAUDIN, Jean-Pierre. Gouverner par contrat: l'action publique en question. Paris: Presses de Sciences Politiques, 1999. p. 14. Cf. DI PIETRO, Maria Sylvia Zanella. Parcerias na administração pública: concessão, permissão, franquia, terceirização e outras formas. 4. ed. São Paulo: Atlas, 2002. p. 33-34.

8 ARIÑO ORTIZ, Gaspar. El retorno a lo privado: ante una nueva encrucijada histórica. tiempo. In: _(Org.). Privatización y liberalización de servicios. Madrid: Universidad Autónoma de Madrid, 1999. p. 19-35. p. 26.

9 NABAIS, José Casalta. Contratos fiscais: reflexōes acerca da sua admissibilidade. Coimbra: Coimbra, 1994. p. 24. 
seus poderes com base na imperatividade e unilateralidade, aceitando realizar acordos com os particulares destinatários da aplicação concreta desses poderes, ganhando assim uma colaboração ativa dos administrados ...". ${ }^{10}$

Certamente que esses fenômenos devem ser interpretados sob a égide do regime jurídico-normativo a que encontra-se vinculada a Administração pública de um dado país. No entanto, o que vem recebendo constantes influxos dessa nova realidade é justamente a disciplina normativa a que são submetidas as relações negociais em que a Administração é parte implicando, além de intensos câmbios na legislação preexistente, a criação de aparatos legislativos mais adequados ao desenvolvimento dessas relações preferencialmente paritárias.

No Brasil, os contratos de parceria público-privada " são um reflexo dos câmbios assinalados, e atualmente configuram objeto de intensos e acalorados debates. Sem desconsiderar que em algumas unidades federativas tenham sido aprovadas leis sobre a matéria, ${ }^{12}$ atualmente a PPP é disciplinada pela Lei federal n. 11.079 , de 30 de dezembro de 2004. ${ }^{13}$

Assiste-se atualmente a uma acentuada divergência quanto a diversos aspectos desse novo contrato da Administração pública brasileira. Com efeito, está-se diante de uma nova figura a ser empregada pelo setor público no campo negocial, a qual visa instituir e formalizar uma relação jurídica entre a Administração pública e os particulares em bases normativas diversas daquelas representadas pelas disposições inseridas nas Leis federais n. 8.666/93 e n. 8.987/95.

As PPPs podem ser entendidas como "parcerias entre autoridades públicas e empresas e investidores do setor privado, com o objetivo de conceber, planificar, financiar, construir e operar projetos de infraestrutura habitualmente prestados através de mecanismos tradicionais como os contratos públicos". ${ }^{14}$

10 FERNÁNDEZ, Tomás-Ramón, GARCİA DE ENTERRİA, Eduardo. Curso ..., v. 1, p. 661.

11 Nesse trabalho, utilizar-se-á a sigla PPP, amplamente difundida para caracterizar os contratos de parceria público-privada.

12 Cf. Lei do Estado de Minas Gerais, n. 14.862, de 16.12.03; Lei do Estado de Santa Catarina, n. 12.930, de 04.02.04; Lei do Estado de São Paulo n. 11.688, de 19.05.04; Lei do Estado de Goiás n. 14.910, de 11.08.04; Lei do Estado do Ceará n 13.557, de 30.12.04 e Lei do Estado do Rio Grande do Sul n 12.234, de 13.01.05.

13 O diploma legislativo assinalado visa instituir normas gerais para licitação e contratação de parceria público-privada, no âmbito dos Poderes da União, dos Estados, do Distrito Federal e dos Municípios. $\mathrm{O}$ projeto de lei foi encaminhado pelo Poder Executivo ao Congresso Nacional em 19.11.03, tendo tramitado na Câmara dos Deputados sob o n. 2.546/2003 e enviado ao Senado Federal em 24.03.04, onde tramitou sob o n. 10/2004.

14 NAMBLARD, Corinne. Para um enfoque pragmático da parceria público-privado. In: CHATELUS, Gautier; PERROT, Jean-Yves (Dir.) Financiamento das infraestruturas e dos serviços coletivos: o recurso à parceria público-privado: os exemplos da experiência francesa no mundo. Paris: DAEI, 1994. p. 13-28. p. 15. Sobre novas formas de contratualização, cf. JUSTEN FILHO, Marçal. As diversas configurações da concessão de serviço público. Revista de direito público da economia, Belo Horizonte, a.1, n. 1, p. 95-136. jan./mar. 2003. 
Inserem-se em um cenário de escassez de recursos orçamentários para a execução de projetos de altos custos, em que existe um grave déficit de projetos estruturantes em áreas como transportes, saneamento básico e saúde. ${ }^{15}$

Ademais disso, a experiência estrangeira para a realização e gestão de grandes infra-estruturas e de serviços coletivos vem fazendo uso da PPP, pois há um entendimento corrente no sentido de que tais contratos traduzem uma forma mais contemporânea de assegurar serviços públicos de melhor qualidade, com menores custos para a sociedade.

Subjacentes a essa nova modalidade contratual estão noções como (i) alta complexidade do objeto, execução e acompanhamento do ajuste, (ii) elevado nível de riscos a serem enfrentados pelos parceiros, em função do montante dos recursos financeiros envolvidos, das incertezas sobre os custos de construção e de operação e das dúvidas atinentes aos rendimentos a rerem alcançados, (iii) estabelecimento de garantias especiais conferidas pelo parceiro público ao parceiro privado, destinadas a assegurar o cumprimento das obrigações assumidas pela Administração, ${ }^{16} \mathrm{e}$ (iv) dificuldade em atingir-se - em sede contratual - a ótima regulamentação dos interesses em jogo, quais sejam, os do parceiro público, do parceiro privado e da coletividade em geral.

Nessa última característica jaz um aspecto que há de ser devidamente salientado, pois manifesta uma (r)evolução em matéria de contratualização no setor público.

Diversamente dos contratos disciplinados pelas Leis federais n. 8.666/93 e $8.987 / 95$, as comumente denominadas cláusulas exorbitantes não estariam, a princípio, presentes de modo tão abundante nas PPPs. Com efeito, a tônica é justamente a ampliação das bases da negociação das cláusulas contratuais que irão estabelecer a regulamentação dos interesses dos parceiros, sem o enfraquecimento da (imanente) bilateralidade desse negócio jurídico.

Como todo e qualquer contrato (privado ou público), o parceiro público e o parceiro privado da PPP desejam obter benefícios da relação. Todavia, tais objetivos naturalmente possuem pontos de convergência $(\nu . g$. sucesso do empreendimento) e pontos de eventual divergência ( $v . g$. assunção dos riscos e divisão dos lucros). As negociações ocorrem para possibilitar um equilíbrio de todos esses interesses, "com vistas a alcançar os compromissos mais justos e eficazes possíveis dentre as perspectivas de ganhos, custos a serem arcados e dos riscos a serem corridos". ${ }^{17}$

Esse equilíbrio será expressado na pactuação das cláusulas do contrato de PPP, cujo conjunto desencadeará efeitos típicos dos contratos sinalagmáticos. E no caso de entender-se que os contratos administrativos regidos pelas Lei federais n. 8.666/93 e 8.987/95 também geram efeitos decorrentes do sinalagma (em verdade é isso o

15 Dados extraídos da palestra Parcerias Público-Privadas: aspectos jurídicos, proferida por Carlos Ari SUNDFELD, no Congresso Ibero-Americano de Direito Administrativo, Curitiba. 2003. 16 O parágrafo único do art. 11 da Lei federal n. 11.079/04 estabelece que "o edital deverá especificar, quando houver, as garantias da contraprestação do parceiro público a serem concedidas ao parceiro privado".

17 NAMBLARD, Corinne. Op. cit., p. 27. 
que ocorre), a carga de efeitos caracteristicamente sinalagmáticos na PPP é muito maior (ou ao menos não é condicionada, debilitada ou neutralizada), se comparada aos efeitos produzidos pelos contratos administrativos tradicionais. ${ }^{18}$

Assim, na PPP parceiro público e parceiro privado simultaneamente ocuparão a posição de credor e de devedor, cujos direitos e obrigações submetem-se (tendencialmente) a um regime de dependência recíproca, em que a obrigação de um corresponde ao direito do outro, e vice-versa. Portanto, na PPP é possível defender que haverá uma forte correlação entre os direitos e as obrigações do parceiro público e do parceiro privado, diferentemente do que acontece nos contratos administrativos tradicionais em que a relação jurídica instaurada é de caráter verticalizado, em função da disciplina normativa que os rege.

Situações como essa levam autores da estirpe de Sabino CASSESE a defender novos paradigmas do Estado, os quais "colocam em discussão todas as noções, temas e problemas clássicos do direito público, da natureza do poder público e de sua atuação legal-racional orientada pèla superioridade da lei, do lugar reservado à lei e de suas implicações (legalidade e tipicidade) para as relações público-privadas". ${ }^{19}$ Um desses novos paradigmas seria o fortalecimento da negociação na esfera da Administração pública, expressada por via de acordos, em que "passam ao primeiro plano a negociação em lugar do procedimento, a liberdade das formas em lugar da tipicidade, a permuta em lugar da ponderação". ${ }^{20}$

Para o autor, o paradigma bipolar Estado-cidadão daria lugar ao paradigama multipolar, em que "interesses privados coincidentes com interesses públicos comunitários estão em conflito com outros interesses públicos, de natureza nacional. Não há distinção ou oposição público-privado, assim como não há uma superioridade do momento público sobre o privado" ${ }^{21} \mathrm{E}$ inerente ao paradigma multipolar é a presença de múltiplos agentes e interessados na discussão de assuntos públicos, fato que eventualmente redunda em acordos, exigindo para tanto "permutas recíprocas, fundadas sobre a negociação". ${ }^{22}$

É inegável que assiste-se hodiernamente a uma aproximação entre o regime de direito público e o regime de direito privado, que aliás constituiu-se em uma das prospecções para a Administração pública contemporânea, apontada por Massimo Severo GIANNINI em 1980.

18 Com relação à bilateralidade, Caio TÁCITO sustenta que "a discriminação entre as hipóteses, tendo como fundamento a natureza própria das obrigações contratuais, está a merecer tratamento no plano normativo que faculte, nos contratos administrativos, equivalência entre partes desiguais, de tal modo que as prerrogativas da Administração não onerem excessivamente a outra parte ou eliminem a fruição de direito do contratante privado" (TÁCITO, Caio. Arbitragem ..., p. 114-115.). 19 CASSESE, Sabino. La arena pública..., p. 159.

20 Ibid., p. 157. Sobre associações mistas, envolvendo diferentes partícipes públicos e privados, cf. FAGUNDES, Maria Aparecida de Almeida Pinto S. Parcerias em projetos de infra-estrutura. Revista de Direito Administrativo, Rio de Janeiro, n. 233, p. 419-429, jul./set. 2003.

21 Ibid., p. 159.

22 Ibid., p. 106. 
À época o autor registrou que "o direito administrativo, como normativa pública de caráter autoritário, tende a reduzir-se, e as zonas que abandona são ocupadas novamente pelo direito privado". ${ }^{23}$ Prosseguindo, asseverou que "o direito que regula a atividade das administrações públicas tende, portanto, a compor-se de uma parte fortemente autoritária - direito administrativo em sentido estrito - e de outra, em que tem-se como válida, ainda que com certas adaptações, a normativa privada". 24

Nesse sentido, defende-se atualmente ser possível à Administração optar por formas de organização e de atuação oriundas do regime privado, ${ }^{25}$ sempre que o ordenamento não veicular uma vedação (explícita ou implícita) que afaste tal opção.

No entanto, não é o caso de posicionar-se favoravelmente à submissão (integral) das relações negociais administrativas aos ditames do regime jurídico privado. Visando a contenção da fuga da Administração pública para o direito privado escreveu-se ser possível a circunscrição da atividade administrativa a um regime privatístico, desde que exija-se da Administração "a par das normas jurídico-privadas, ter em consideração certas normas e princípios gerais do Direito Público".26

Sob o enfoque eminentemente contratual, essas transformações não passam desapercebidas por Romeu Felipe BACELLAR FILHO:

Todavia, se, na vigência do antigo Código Civil brasileiro, os contratos de direito privado estavam alicerçados em princípios opostos aos contratos administrativos, as recentes alterações do novo Código Civil caminham num sentido de aproximação dos institutos. O pacta sunt servanda, que constituía mola mestra dos contratos regidos pelo direito privado, foi substituído pelo princípio da função social dos contratos, como se depreende do art. 421 do novo Código Civil: "A liberdade de contratar será exercida em razão e nos limites da função social do contrato". A concepção social do contrato apresenta-se, modernamente, como um dos pilares da teoria contratual. Defronta-se com o vetusto princípio pacta sunt servanda, exaltado, expressamente, pelos Códigos Civil francês (art. 1.134) e italiano (art. 1.372) para, atenuando a autonomia da vontade, promover a realização de um justiça comutativa. A moldura limitante do contrato tem o escopo de acautelar as desigualdades substanciais entre os contraentes, como adverte José Lourenço, valendo como exemplo os contratos de adesão. O negócio jurídico haverá de ser fixado em seu conteúdo, segundo a vontade das partes. Esta, todavia,

23 GIANNINI, Massimo Severo. Premisas sociológicas e históricas del derecho administrativo. Madrid: Instituto Nacional de Administración Pública, 1987. p. 83.

24 Ibid., p. 83-84.

25 Cf. MOREIRA, Vital. Organização Administrativa. Coimbra: Coimbra Editora, 2001.

26 ESTORNINHO, Maria João. A fuga para o direito privado. Coimbra: Almedina, 1996. p. 160-161. Cf. ainda RIVERO ORTEGA. Ricardo. Administraciones públicas y derecho privado. Madrid: Marcial Pons, 1998. 
apresenta-se auto-regrada em razão e nos limites da função social, princípio determinante e fundamental que, tendo origem na valoração da dignidade humana (art. $1^{\circ} \mathrm{CF}$ ), deve prescrever a ordem econômica e jurídica. ${ }^{27}$

É nesse ambiente de transição que insere-se a discussão da conformação jurídica de um contrato administrativo com as características da PPP. É nesse cenário em mutação que defende-se - senão a equiparação entre Administração pública e particular nas atividades de índole negocial - uma acentuada (e juridicamente protegida) interdependência entre as prestações a cargo de ambas as partes. Finalmente, é nesse âmbito de interseção dos interesses públicos e dos interesses privados - uma realidade constatada, e não uma tendência a ser assimilada - que há de ser desenvolvida a possibilidade da utilização da via arbitral para o deslinde de controvérsias ocorridas em sede de contratualização administrativa.

No entanto, é a nova contratualização administrativa (ainda em formação), desenvolvida em amplas bases negociais, que parece sinalizar para uma maior paridade entre Administração e particular.

É o que será discutido no item a seguir.

2. Uma nova contratualização administrativa: rumo à paridade nas relações contratuais?

A negociação não constitui uma novidade do Estado contemporâneo.

Há tempos o Estado reconhece e utiliza métodos consensuais, consagrando os contratos como formas adequadas à instrumentalização de compromissos no território das relações patrimoniais. Isso acontece sobretudo quando o objetivo visado é (i) adquirir bens e serviços junto à iniciativa privada ou (ii) a ela transferir a execução de atividades estatais qualificadas como serviços públicos. É o campo denominado por Eduardo GARCÍA DE ENTERRÍA e Tomás-Ramón FERNÁNDEZ de colaboração ou intercâmbio patrimonial, em que a Administração pública "paga dinheiro ou transfere possibilidades de atuações a ela reservadas em troca de bens ou de serviços que busca e que recebe". ${ }^{28}$

Embora tenha havido forte resistência à aceitação do contrato como um modo normal de atuação da Administração pública, ${ }^{29}$ consolidou-se ao final a compatibi-

27 BACELLAR FILHO, Romeu Felipe. Contrato administrativo. In: et al (Coord.). Direito administrativo contemporâneo: estudos em memória ao Professor Manoel de Oliveira Franco Sobrinho. Belo Horizonte: Fórum, 2004. p. 307-326. p. 317. Sobre o tema, cf. SOTO KLOSS, Eduardo. La contratacion administrativa: um retorno a las fuentes classicas del contrato. Revista de administración publica, Madrid, n. 2, p. 569-585, 1978.

28 FERNÁNDEZ. Tomás-Ramón, GARCÍA DE ENTERRÍA, Eduardo. Curso ..., v. 1, p. 660.

29 Tal negação do contrato no âmbito do direito público originou soluções na Itália e Alemanha como a teoria dos dois degraus ou teoria dos dois niveis (Doppio grado e Zweistufentheorie), em que emite-se um ato administrativo seguido de um contrato de direito privado, especificamente para aquelas situações que necessariamente demandassem regulação consensual mínima. Cf. ES- 
lização da lógica da autoridade com a lógica do consenso, ${ }^{30}$ redundando na figura do contrato administrativo como uma categoria jurídica do direito administrativo.

Indubitavelmente, é a vinculação direta e imediata ao interesse público o elemento que qualifica um contrato como sendo um contrato administrativo.

Hector Jorge ESCOLA afirma que "os contratos administrativos (...) têm uma finalidade específica e própria (...) qual seja, a satisfação e o atingimento do interesse público, das necessidades coletivas, sendo precisamente essa finalidade a que thes confere e define a natureza jurídica, efeitos e consequências específicas". ${ }^{31}$ Continuando, o autor explicita que em virtude disso os contratos administrativos "estão sujeitos a formalidades especiais, previstas pelo direito administrativo, podendo conter cláusulas que são exorbitantes do direito privado, mas admissíveis no direito público". ${ }^{32}$

Um contrato administrativo é um negócio jurídico bilateral, pois para a sua formação demanda-se o obrigatório concurso de ao menos duas declarações de vontade, sendo que uma delas há de provir necessariamente de uma Administração pública. Nesse ponto reside a exigência do prévio consenso das partes, fator que acarretará a formação do vínculo gerador dos efeitos jurídicos típicos de uma relação administrativa de índole contratual.

Entretanto, insta acentuar que uma das conseqüências da imprescindível bilateralidade do contrato administrativo não é a equiparação ou igualdade de posições entre as partes, e sim o nivelamento das vontades declaradas ou, na expressão de José Manuel Sérvulo CORREIA, a "igual valia das vontades". ${ }^{33}$

Salienta José Casalta NABAIS:

... para que se possa falar de contrato exige-se uma igualdade das partes, uma igualdade que passa aqui pelo facto de ser justamente o acordo de

TORNINHO, Maria João. Requiem pelo contrato administrativo. Coimbra: Almedina, 1990. p. 169 e ss.

30 É o que Celso Antônio BANDEIRA DE MELLO denomina lógica do contrato administrativo, em que "de um lado, o Poder Público usufrui de todos os poderes indispensáveis à proteção do interesse público substanciado no contrato. (...) De outro, cabe ao particular integral garantia aos interesses privados que ditaram sua participação no vínculo, consoante os termos ali constituídos" (BANDEIRA DE MELLO, Celso Antônio. Curso de direito administrativo. 15. ed. São Paulo: Malheiros, 2003. p. 572-573.). Para o autor, "há duas ordens de interesses que se devem compor na relação em apreço. $O$ interesse público, curado pela Administração, reclama dele flexibilidade suficiente para atendimento das vicissitudes administrativas e variaçōes a que está sujeito. $O$ interesse particular postula suprimento de uma legítima pretensão ao lucro, segundo os termos convencionados" (Ibid., p. 573.). Em síntese, trata-se da "conjugação da consensualidade (própria de todo o contrato) com a autoridade (própria do contrato administrativo)" (GONÇALVES, Pedro. O contrato administrativo. Coimbra: Almedina, 2003. p. 32.).

31 ESCOLA, Héctor Jorge. El interés público como fundamento del derecho administrativo. Buenos Aires: Depalma, 1989. p. 160.

32 Id.

33 CORREIA, José Manuel Sérvulo. Legalidade e autonomia contratual nos contratos administrativos. Coimbra: Almedina, 1987. p. 347. 
ambas as partes necessário e indispensável à formação (constituição) e à manutenção (subsistência) do contrato, o qual assim deve a sua existência e o seu poder vinculativo em igualdade (...) a cada uma das partes contratantes. ${ }^{34}$

Em razão da magnitude dos interesses perseguidos e geridos pela Administração pública (interesse público), não seria incorreto afirmar que perante a atual conformação jurídico-normativa dos contratos administrativos, se os efeitos da bilateralidade encontram-se fortes na formação dos contratos administrativos, os mesmos vão sendo relativamente diluídos ou enfraquecidos no transcurso da relação instaurada pelo ajuste.

Na execução dos contratos administrativos isso se torna evidente, pois o ordenamento confere à Administração-contratante prerrogativas de atuação unilateral sobre o particular-contratado, independentemente de sua prévia aquiescência. Nas formas de extinção dos contratos administrativos esses poderes unilaterais igualmente são previstos no ordenamento, pois há hipóteses de extinção do vínculo contratual por vontade exclusiva da contratante, sem que para isso o contratado concorra com sua culposa inexecução.

E mesmo na formação dos contratos administrativos visualiza-se um abrandamento dos efeitos oriundos dessa bilateralidade, pois uma das características de tais ajustes encontra-se no fato de representarem autênticos contratos de adesão, com a imposição, pela Administração pública, da quase totalidade das cláusulas que comporão o quadro regulatório da relação. Por isso André de LAUBADÈRE sustenta que "o contrato administrativo é um contrato desigualitário, mas um contrato desigualitário não é um ato unilateral". ${ }^{35}$

Atualmente discute-se na doutrina acerca da extensão e da intensidade com que técnicas negociais ou consensuais vêm sendo empregadas como soluções preferenciais - e não unicamente alternativas - à utilização de métodos estatais que veiculem unilateral e impositivamente comandos para os cidadãos, empresas e organizações da sociedade civil. Por isso, uma das linhas de transformação do direito administrativo consiste em evidenciar que, no âmbito estatal, em campos habitualmente ocupados pela imperatividade há a abertura de consideráveis espaços para a consensualidade.

Certamente essa nova orientação tem impacto na atividade negocial da Administração pública.

Em 1967 André de LAUBADERE ressaltou que na esfera administrativa o contrato sempre ocupou um lugar relativamente limitado, desempenhando papéis bem definidos, consistindo a intervenção unilateral de via autoritária a forma usual de obter do administrado os comportamentos visados pela Administração. Não

NABAIS. José Casalta. Op.cit., p. 23.

35 LAUBADÈRE, André et al. Traité des contrats administratifs. Paris: L.G.D.J., 1983. v. 1, p. 71. 
obstante tal constatação, o autor colocava em relevo a emergência de um novo modo de administrar: a administração por meio do contrato.

Apresentou o autor dois fatores para o impulso dessa nova forma de administrar.

O primeiro fator estaria relacionado com "o considerável aumento quantitativo dos objetivos considerados como sendo de interesse geral", ${ }^{36}$ tornando necessário recorrer à "ação paralela dos administrados, por meio da natural realização de acordos". ${ }^{37}$ Para conferir resposta a essa demanda, o autor propôs a utilização dos contratos de colaboração, "levando-se em conta o sentido mais abrangente e variado da expressão". 38

O segundo fator corresponderia ao fato de que seria mais fácil à Administração "administrar com a adesão do administrado do que contra a sua vontade, tratando-o como participante e não como subordinado" ${ }^{39}$ E para atender a essa finalidade, sugeriu a adoção da expressão contratos de administração, em que é "a própria ação administrativa que constitui-se em conteúdo do contrato" ${ }^{40} \mathrm{E}$ a partir dessa espécie de contratos - inicialmente aplicadas pelo Estado no campo econômico - "a administração pode ser levada a preferir a via do contrato àquela da ação unilateral, porque os complexos mecanismos da atividade econômica nem sempre permitem que intervenções imperativas e impositivas tenham eficácia". ${ }^{41}$

Com efeito, da conjugação dos fatores acima apresentados solidificam-se as bases da Administração pública consensual.

Diante do incremento quantitativo e qualitativo da atividade negocial Administração pública-particular, abrandou-se sensivelmente o primado da autoridade como eixo principal para o desenvolvimento das relações travadas entre a Administração e os destinatários de sua atividade. Essa atividade negocial transbordou o campo das relações econômicas, imprimindo novos formatos às colaborações público-privadas, em áreas afetas aos serviços públicos (revalorização dos contratos de concessões de serviços públicos) e especialmente aos serviços de infra-estrutura (contratos de parceria público-privada-PPP). Estendeu-se ao segmento dos serviços sociais não lucrativos, e principalmente, passou a incidir sobre conteúdos cuja determinação e veiculação tradicionalmente operava-se pela via unilateral do ato administrativo. ${ }^{42}$

36 LAUBADÈRE, André. Administration et contrat. In: LAUBADÈRE, André et al. Pages de doctrine. Paris: L. G. D. J., 1980. v. 2, p. 239-252. p. 240.

37 Id.

38 Id.

39 Id.

40 Id.

41 Ibid., p. 247.

42 Cumpre ressaltar que outra faceta da Administração pública consensual revela-se no terreno das relações Administração pública-Administração pública, ou seja, no campo organizacional. Nesse campo vem ocorrendo uma profunda transformação, tendente a dotar a ação administrativa de maior efícácia e eficiência, com a simplificação de seus procedimentos e sobretudo conferindo maior efetividade aos resultados alcançados. Nova conotação e objetivos ganhou a atividade de coordenação administrativa, agora aplicada a uma complexa organização policêntrica, em que deve 
Assim, não há como negar a retração da Administração de cunho autoritário, movimento acompanhado do sensível avanço da Administração baseada em acordos, ou simplesmente Administração pública consensual.

No entanto, a afirmação há de ser assimilada com algum temperamento.

A Lei alemã de Procedimento Administrativo, editada em 1976 estabelece a noção de contrato de direito público, cujo significado traduz precisamente o impulso conferido à Administração consensual na atualidade. No parágrafo 54 do diploma aludido consta que "uma relação jurídica de direito público pode ser criada, modificada ou extinta por contrato (contrato de direito público), desde que isso não seja vedado por lei. Especialmente, pode a Administração. em lugar de editar ato administrativo, celebrar contrato de direito público com quem seria o destinatário do ato administrativo".

A disciplina normativa germânica ${ }^{43}$ expressa a consagração do fenômeno da administração por acordos, o qual espraiou-se para diversos outros países europeus.

A Lei italiana n. 241, de 7 de agosto de 1990 prescreve em seu art. 11 que “... a Administração competente pode concluir, sem prejuízo dos direitos de terceiros, e sempre em atendimento ao interesse público, acordos com os interessados, com o fim de determinar o conteúdo discricionário da decisão final ou, nos casos previstos em lei, a substituição da mesma" ${ }^{44}$

Na Espanha, o art. 88.1 da Lei n. 30/1992 (Regime Jurídico das Administrações Públicas e do Procedimento Administrativo Comum - LRJ-PAC) estipula que "as administrações públicas poderão celebrar acordos, pactos, convênios ou contratos com pessoas de direito público ou de direito privado, sempre que não sejam contrários ao Ordenamento jurídico, nem versem sobre matérias não suscetíveis de transação e tenham por objeto satisfazer o interesse público a elas confiado, com o alcance, efeitos e regime jurídico específico que em cada caso preveja a disposição que o regule, podendo tais atos representar o término dos procedimentos administrativos,

ser respeitada a autonomia dos órgãos e entidades envolvidas. Forte impulso recebeu a tarefa de cooperação administrativa, mormente em campos objeto de competências partilhadas que demandam maior agilidade e articulação para o mútuo desenvolvimento de atividades afins. Prestigia-se a atividade do planejamento no setor público, caracterizado como " método coerente e compreensivo de formação e implementação de diretrizes, através de um controle central de vastas redes de órgãos e instituições interdependentes, viabilizado por conhecimentos científicos e tecnológicos" (LOPES, Carlos Thomas G. Planejamento, estado e crescimento. São Paulo: Pioneira, 1989. p. 24.). Nessa oportunidade, essa vertente não será explorada.

43 Informações extraídas de COUTO E SILVA, Almiro. Os indivíduos e o Estado na realização de tarefas públicas. Revista de direito administrativo, Rio de Janeiro, v. 209, p. 43-70, jul./set. 1997. p. 65: MASUCCI, Alfonso. Trasformazione.... p. 62 e ss., e RODRÍGUEZ DE SANTIAGO, José Maria. Los convenios entre administraciones públicas. Madrid: Marcial Pons, 1997, p. 51-66.

44 Cf. AICARDI, Nicola. La disciplina generale e i principi degli accordi amministrativi: fondamento e caratteri. Rivista trimestrale di diritto pubblico, Roma, a. 47, n. 1. p. 1-59, 1997; ALBERTI, Piergiorgio et al. (org.). Lezioni sul procedimento amministrativo. 2. ed. Torino: G. Giappichelli. 1995: BARBAGALLO, Giuseppe et al. (org.) Gli accordi fra privati e pubúlica amministrazione e la disciplina generale del contrato. Napoli: Edizioni Scientifiche Italiane, 1995. 
ou inserir-se nos mesmos em caráter prévio, vinculante ou não, à decisão que os finalize".45

O Código do Procedimento Administrativo de Portugal reconhece a existência, no art. 185,3 , (a) dos "contratos administrativos com objecto passível de acto administrativo".

Em face de todos os dispositivos acima aludidos, resta claro que tanto o ato administrativo, quanto o contrato administrativo, são atualmente entendidos como formas jurídicas adotadas pela Administração pública para a consecução de suas tarefas. Ato e contrato configuram, pois, instrumentos de ação administrativa.

Por isso, adota-se nesse trabalho a conceituação elaborada por José Manuel Sérvulo CORREIA, para quem contrato administrativo é "um processo próprio de agir da Administração pública e que cria, modifica ou extingue relações jurídicas, disciplinadas em termos específicos do sujeito administrativo, entre pessoas colectivas da Administração ou entre a Administração e os particulares". ${ }^{46} \mathrm{O}$ autor aduz que "encarar o contrato administrativo como processo próprio de agir da Administração pública não equivale a reivindicar a total autonomia da figura relativamente à do contrato em geral". 47 Prossegue, ponderando que tanto o ato administrativo como o "contrato regido pelo direito estatutário da Administração" 48 têm o condão de criar, modificar ou extinguir relações jurídicas de direito administrativo.

Assim, insta esclarecer que a emergência da administração consensual não resulta - e nem poderia resultar - no aniquilamento da administração por atos. A administração consensual não supera a administração imperativa, mas seguramente diminui o seu campo de incidência.

As transformações assinaladas - circunscrição da atividade administrativa impositiva a certos campos, com a expansão do consensualismo para considerável parcela das atividades perpetradas pela Administração - provocam uma mudança de eixo do direito administrativo, que passa a ser orientado pela lógica da autoridade continuamente permeada e temperada pela lógica do consenso.

Tais câmbios acabam reverberando na atividade contratual da Administração Pública, suscitando uma reformulação da tradicional abordagem dos procedimentos pré-negociais e negociais, com maior favorecimento à discussão acerca das cláusulas que irão reger a relação jurídica a ser instaurada pela via do ajuste.

As PPPs encaixam-se nessa nova fase da contratualização administrativa ou simplesmente nova contratualização administrativa (ainda em evolução), em que (i) privilegia-se sobremaneira a cultura do diálogo entre o parceiro público e o privado, (ii) confere-se maior atenção às negociações preliminares ao ajuste (que

45 Cf. PALMA DEL TESO, Ángeles de. Los acuerdos procedimentales en el derecho administrativo. Valencia: Tirant lo blanch, 2000; FERNÁNDEZ, Tomás-Ramón, GARCIA DE ENTERRfA, Eduardo. Curso de derecho administrativo. 6. ed. Madrid: Civitas, 1999. v. 2, p. 498-500.

46 CORREIA, José Manuel Sérvulo. Legalidade ..., p. 396.

47 Id.

48 Id. 
devem ser transparentes), ${ }^{49}$ (iii) abrem-se espaços para trocas e concessões mútuas entre os parceiros, visando um balanceamento dos interesses envolvidos, (iv) diminui-se a imposição unilateral de cláusulas por parte da Administração, com o proporcional aumento da interação entre os parceiros para o delineamento e fixação das cláusulas que integração o contrato e (v) institui-se uma maior interdependência entre as prestações correspondentes ao parceiro público e ao parceiro privado, inclusive com a atribuição de garantias a esse último, tidas como não usuais nos contratos tradicionais firmados pela Administração.

Todas essas diferentes perspectivas da atuação negocial levada a cabo em sede administrativa abalam o dogma da verticalização das relações contratuais entre Administração e particular, sinalizando um maior equilíbrio nas posições assumidas por ambas as partes.

Ademais disso, constatada uma evolução no desenvolvimento das relações administrativas em geral (admite-se o contrato, ao lado do ato administrativo, como um "processo próprio do agir da Administração pública" ${ }^{50}$ ) parece claro que essa nova forma do agir administrativo resulta na ampliação das bases consensuais naquele campo em que consenso e bilateralidade são elementos indispensáveis: a atividade administrativa negocial.

É demasiadamente prematuro firmar posições sobre os câmbios que essas novas perspectivas podem desencadear na teoria geral dos contratos administrativos. No entanto, parece que uma forte linha de transformação reside no (relativo) superamento da premissa do desnivelamento do particular-contratado em face da Administração-contratante, como elemento de caracterização de todo e qualquer contrato administrativo.

A nova contratualização administrativa afina-se com uma construção de grande repercussão mundial na atualidade, a formulação do Estado do Investimento Social, de autoria de Anthony GIDDENS, um dos idealizadores da versão contemporânea da terceira via. ${ }^{51}$

49 A versão final do PL n. 2.546/2003 relativo à PPP, aprovada pela Câmara dos Deputados estipula no par. 3 do art. 10 que "o projeto de parceria público-privada será objeto de audiência pública, com antecedência mínima de trinta dias da publicação do edital da respectiva licitação, mediante a publicação de aviso na imprensa oficial, em jornais de grande circulação e por meio eletrônico, na qual serão informadas a justificativa para a contratação, a identificação do objeto, o prazo de duração do contrato e seu valor estimado, fixando-se prazo para oferecimento de sugestões, cujo termo dar-se-á pelo menos com sete dias de antecedência da data prevista para a publicação do edital".

50 CORREIA, José Manuel Sérvulo. Legalidade ..., p. 396.

51 Norberto BOBBIO explica que o termo procura indicar a "ideologia segundo a qual uma meta, que é o socialismo, pode e deve ser alcançada através de um método, que é a democracia" (BOBBIO, Norberto. A via democrática. In: As ideologias e o poder em crise. 4. ed. Brasília: Editora Universidade de Brasília, 1999. p. 160-164. p. 160.). GIDDENS define a terceira via como uma estrutura de pensamento e de prática política que visa adaptar a social-democracia a um mundo que se transformou fundamentalmente ao longo das duas últimas décadas. É uma terceira via no sentido de que "é uma tentativa de transcender tanto a social-democracia do velho estilo quanto o neoliberalismo" (GIDDENS, Anthony. A terceira via. Rio de Janeiro: Record, 2000. p. 36.). 
Partindo da crise do Estado do Bem-estar Social, o autor propõe uma nova forma de organização da economia, denominada economia mista. Por meio dela, buscar-se-ia uma sinergia entre os setores público e privado, com a utilização do dinamismo dos mercados sem perder de vista o interesse público. Afirma que esse modelo econômico "envolve um equilíbrio entre regulação e desregulação, num nível transnacional bem como em níveis nacional e local; e um equilíbrio entre o econômico e o não-econômico na vida da sociedade". 52

Assim, ajustes que pretendam formalizar parcerias entre os setores público e privado, visando promover o desenvolvimento dos indivíduos, da sociedade e do país, notadamente por meio da melhoria dos serviços públicos de infra-estrutura, devem ser permeados por novos parâmetros e instrumentalizados por meio de novas formas jurídicas.

Há um itinerário obrigatório a ser percorrido pelo ente estatal, mormente em respeito aos valores fundamentais do Estado Brasileiro dispostos no art. $1^{\circ}$ da Lei Maior. Isso significa que mesmo diante da escassez de recursos públicos - fato que eventualmente pode ser tido como obstáculo para a efetivação de direitos sociais pela via direta da prestação de serviços públicos - o Estado não pode isentar-se de suas responsabilidades nesse campo.

A ele cumpre levar a cabo uma série de outras ações ( $v . g$. fomento, regulação, incentivo, parcerias), as quais visam promover esse valores fundamentais. Basicamente, tais medidas ou providências tendem a perseguir o desenvolvimento, o qual tem em seu cerne a valorização da pessoa humana. ${ }^{53}$

Estado, Governo e Administração pública constituem-se, portanto, em intermediadores e promotores constitucionalmente vocacionados do desenvolvimento nacional. Optando pela parceria com a iniciativa privada para atingir esse fim, resta claro que o parceiro privado estará em uma posição distinta das situações ocupadas pelo particular enquanto mero fornecedor de bens e serviços, ou mesmo delegatário para a execução de serviços públicos nos termos e na forma em que a Administração determinar.

Nesse sentido, o vetor da paridade das relações contratuais em ajustes que visem atingir tais desideratos parece ser a tônica da nova contratualização administrativa. Essa paridade é manifestada notadamente na fase pré-negocial (negociações preliminares) e na fase de formação dos contratos que correspondam a esse novo perfil, como é o caso da PPP. Também nas fases de execução e extinção desses contratos a tendência - em razão da própria noção de parceria - caminha para novas bases consensuais e paritárias, com a possibilidade de redução do feixe de

\section{GIDDENS, Anthony. A terceira ..., p. 110.}

53 Romeu Felipe BACELLAR FILHO ressalta que "os princípios constitucionais possuem marca distintiva, embora atuem conjugadamente, complementando-se, condicionando-se e modificando-se em termos recíprocos. Tudo porque assentam-se em base antropológica comum: a dignidade da pessoa humana" (BACELLAR FILHO, Romeu Felipe. Princípios constitucionais do processo administrativo disciplinar. 2. ed. São Paulo: Max Limonad, 2003. p. 149.). 
poderes unilaterais pela Administração, até hoje largamente utilizados no transcurso das relações contratuais..

Entretanto, mister é enfatizar que tais considerações não transmudam a PPP em um contrato de direito privado. Longe disso, por ser uma espécie de contrato administrativo, dele farão parte cláusulas que assegurem à Administração exercer sua potestade na proporção necessária ao resguardo dos interesses públicos envolvidos. ${ }^{54}$ Mas é justamente a medida, a intensidade e a extensão do exercício dos poderes unilaterais da Administração, no curso da relação contratual, que podem e devem passar por uma filtragem, a partir dos ressaltados aspectos e fundamentos da nova contratualização administrativa.

Trata-se de temática recém-inaugurada no direito administrativo brasileiro, sobre a qual a doutrina certamente ainda irá debruçar-se, produzindo estudos mais aprofundados.

Nessa oportunidade, será apreciada a utilização do juízo arbitral para a solução de litígios e controvérsias originados de relações jurídicas cujo perfil amolda-se à nova contratualização administrativa. Contudo, impõe-se preliminarmente realizar uma síntese da atual disciplina geral da arbitragem no direito brasileiro, com destaque para a problemática envolvendo a matéria administrativa.

\section{A arbitragem no direito brasileiro}

Carlos Alberto CARMONA conceitua arbitragem como "meio alternativo de solução de controvérsias através da intervenção de uma ou mais pessoas que recebem seus poderes de uma convenção privada, decidindo com base nela, sem intervenção estatal, sendo a decisão destinada a assumir a mesma eficácia da sentença judicial". 55

A Lei federal n. 9.307/96 - Lei da Arbitragem (LA) veicula a disciplina jurídica da matéria no direito brasileiro, estabelecendo que por intermédio da convenção de arbitragem as partes interessadas poderão submeter a solução de litígios ao juízo arbitral (árbitro ou Tribunal arbitral).

Tal convenção poderá ser acordada por meio da cláusula compromissória, compreendida como a convenção pactuada em cláusula contratual, em que as partes "comprometem-se a submeter à arbitragem os litígios que possam vir a surgir, relativamente a tal contrato" (art. $4^{\circ}$ da LA). O art. 853 do Novo Código Civil admite que seja ajustada contratualmente a cláusula compromissória, com o intuito de

54 Marçal JUSTEN FILHO pondera que "o núcleo do Direito Administrativo não é o poder (e suas conveniências), mas a realização do interesse público - entendido como afirmação da supremacia da dignidade da pessoa humana" (JUSTEN FILHO, Marçal. Conceito de interesse público e a "personalização" do direito administrativo. Revista Trimestral de Direito Público, São Paulo, n. 26, p. 115-136, 1999. p. 129.). Sobre a evolução do conceito de interesse público, cf. MEDAUAR, Odete. $O$ direito administrativo em evolução. 2. ed. São Paulo: RT, 2003. p. 185-194. 55 CARMONA, Carlos Alberto. Arbitragem e processo: um comentário à lei n. 9.307/96. 2. ed. São Paulo: Atlas, 2004. p. 51. 
resolver divergências mediante juízo arbitral, na forma da lei especial, ou seja, na forma da LA.

A outra forma dos interessados determinarem a submissão de um litígio à arbitragem é o compromisso arbitral, o qual, nos termos do art. $9^{\circ}$ da LA poderá ser judicial ou extrajudicial. O Novo Código Civil estatui em seu art. 851 que "é admitido compromisso, judicial ou extrajudicial, para resolver litígios entre pessoas que podem contratar".

Em face do art. $1^{\circ}$ da LA, a doutrina alude a uma arbitrabilidade subjetiva e a uma arbitrabilidade objetiva. Assim, somente podem pactuar e sujeitar-se a arbitragem as pessoas capazes de contratar (arbitrabilidade subjetiva); e somente podem ser submetidos ao juízo arbitral controvérsias atinentes a direitos patrimoniais disponiveis (arbitrabilidade objetiva).

No que tange à arbitrabilidade objetiva, o art. 852 do Novo Código Civil veicula regra similar à do art. $1^{\circ}$ da LA, dispondo ser "vedado compromisso para solução de questões de estado, de direito pessoal e de outras que não tenham caráter estritamente patrimonial". Reforça a Lei Civil o caráter de disponibilidade dos direitos como conditio sine qua non para que possa ser validamente empregado o método arbitral de solução de litígios, estipulando no art. 841 que "só quanto a direitos patrimonias de caráter privado se permite a transação".

A LA afastou totalmente a possibilidade da via arbitral para a solução de controvérsias envolvendo direitos indisponíveis, pois em seu art. 25 determina a obrigatoriedade da suspensão do procedimento arbitral para que o Poder Judiciário possa apreciar e decidir acerca de controvérsia sobre direitos indisponíveis, desde que (i) a mesma tenha surgido em seu curso e (ii) constitua questão prejudicial à solução do litígio no juízo arbitral.

Constatando que encontra-se superada a discussão sobre a constitucionalidade do procedimento arbitral no direito brasileiro, ${ }^{56}$ impõe-se examinar as razőes que afastariam os litígios envolvendo contratos firmados pela Administraçăo pública do campo de abrangência do juízo arbitral.

Com relação à arbitrabilidade subjetiva, parece não haver dúvidas de que o ordenamento genericamente confere ao Estado capacidade para comprometer-se e contratar, aptidão que é inferida de sua personalidade jurídica de direito público. As entidades administrativas que integram a organização administrativa em sua feição indireta ( $v . g$. autarquias, empresas públicas, etc.) também gozam de capacidade de contratar, como decorrência da personalidade jurídica de que são dotadas.

No âmbito das relações $e$ dos contratos internacionais, há exemplos da submissão do Estado ao juízo arbitral. Com relação ao Mercado Comum do Sul MERCOSUL, em 1991 o Protocolo de Brasilia estabeleceu o procedimento arbitral como uma das formas de solução das controvérsias que surgirem entre os Estados Partes sobre a interpretação, a aplicação ou descumprimento das disposições contidas no Tratado de Assunção, dos acordos celebrados no âmbito do mesmo, bem como

36 Supremo Tribunal Federal, Sentença Estrangeira n. 5.206-7, Rel. Min. Sepúveda PERTENCE, j. em 12.12.2001. 
das decisões que emanem do Conselho do Mercado Comum (Decreto n. 922/93). De outro lado, o Decreto-lei n. 1.960/82 preceitua que "fica o Poder Executivo autorizado a contratar ou garantir, em nome da União, sob a forma de fiança, o pagamento das prestações devidas por autarquias, empresas públicas, sociedade de economia mista ou outras entidades controladas, direta ou indiretamente, pela União ou Estado federado, em decorrência de operações de arrendamento mercantil, com opção de compra, ajustadas com entidades ou empresas sediadas no exterior" (art. $\left.1^{\circ}\right)$. $\mathrm{O}$ art. $2^{\circ}$ desse diploma normativo admite, em seu inciso $\mathrm{V}$, a inclusão nesses contratos de cláusula que estipule que os litígios deles decorrentes poderão ser resolvidos "perante o foro brasileiro ou submetidos à arbitragem".

Ora, se isso ocorre no campo das relações internacionais, parece correto afirmar que aparentemente não haveria qualquer entrave para que, sob o ponto de vista subjetivo, o Estado pudesse firmar convenção de arbitragem e sujeitar-se ao juízo arbitral para que controvérsias de cunho contratual fossem nessa via solucionadas.

Apreciando o desenvolvimento da arbitragem na França, Apostolos PATRIKIOS destaca a aceitação da arbitragem em matéria administrativa internacional. Todavia, enfatiza que no que diz respeito a sua aplicação nos litígios internos, "seria legítimo defender uma extensão do campo da arbitragem, mas não a sua generalização. É a natureza do próprio direito administrativo que se opõe à evolução desse instituto". 57

Portanto, é na seara da arbitrabilidade objetiva que reside o argumento ainda encarado como sendo o mais desfavorável à admissão do meio arbitral como forma de resolução de conflitos envolvendos contratos firmados pela Administração pública. Trata-se da indisponibilidade do interesse público, entendida como a viga mestra do regime jurídico-administativo.

Em virtude dessa impossibilidade de dispor do interesse público, há quem afirme que todos os interesses e direitos integrantes do conteúdo das relações contratuais firmadas no setor público seriam indisponiveis, tornando impossível a eleição da via arbitral para a solução dos litígios envolvendo questões contratuais.

Carlos Alberto CARMONA afirma que são arbitráveis "as causas que tratem de matérias a respeito das quais o Estado não crie reserva específica por conta do resguardo dos interesses fundamentais da coletividade, e desde que as partes possam livremente dispor acerca do bem sobre que controvertem". ${ }^{58}$

A sinalização apontada pelo autor merece ser observada.

Como bem aponta Eros Roberto GRAU, "não há qualquer correlação entre disponibilidade ou indisponibilidade de direitos patrimoniais e disponibilidade ou indisponibilidade do interesse público". ${ }^{59}$ [sem grifo no original] Diante da clareza e do acerto das afirmações, cumpre transcrever os ensinamentos do Ministro do Supremo Tribunal Federal:

GRAU, Eros Roberto. Arbitragem ..., p. 20 
Dispor de direitos patrimoniais é transferi-los a terceiros. Disponíveis são os direitos patrimoniais que podem ser alienados. A Administração, para a realização do interesse público, pratica atos, da mais variada ordem, dispondo de determinados direitos patrimoniais, ainda que não possa fazê-lo em relação a outros deles. Por exemplo, não pode dispor dos direitos patrimoniais que detém sobre os bens públicos de uso comum. Mas é certo que inúmeras vezes deve dispor de direitos patrimoniais, sem que com isso esteja a dispor do interesse público, porque a realização deste último é alcançada mediante a disposição daqueles. (...) Daí porque, sempre que puder contratar, o que importa disponibilidade de direitos patrimoniais, poderá a Administração, sem que isso importe disposição do interesse público, convencionar cláusula de arbitragem..$^{60}$ [sem grifo no original]

No mesmo sentido, Caio TÁCITO:

$\mathrm{Na}$ medida em que é permitido à Administração Pública, em seus diversos órgãos e organizações, pactuar relações com terceiros, especialmente mediante a estipulação de cláusulas financeiras, a solução amigável é fórmula substitutiva do dever primário de cumprimento da obrigação assumida. Assim como é lícita, nos termos do contrato, a execução espontânea da obrigação, a negociação - e, por via de consequiência, a convenção de arbitragem será meio adequado de tornar efetivo o cumprimento obrigacional quando compatível com a disponibilidade de bens. Em suma, nem todos os contratos administrativos envolvem, necessariamente, direitos indisponíveis da Administração. ${ }^{61}$ [sem grifo no original]

Diogo de Figueiredo MOREIRA NETO afirma que "são disponíveis (...) todos os interesses e os direitos deles derivados que tenham expressão patrimonial, ou seja, que possam ser quantificados monetariamente, e estejam no comércio, e que são, por esse motivo e normalmente, objeto de contratação ...". ${ }^{62}$

Ora, sendo o contrato administrativo um processo próprio do agir administrativo, parece claro que a admissão, no ordenamento pátrio, da possibilidade da Administração contratar implica conferir-lhe o direito de certa margem de negociação e disposição sobre determinados interesses, bens e direitos. É óbvio que tanto essa negociação, quanto essa disposição encontram-se regidas, condicionadas pelo regime jurídico-administrativo brasileiro.

No entanto, havendo uma previsão legal (genérica que seja), acerca da afetação de bens ou inalienabilidade de bens e direitos por parte da Administração, tais bens

60 Id.

61 TÁCITO, Caio. A arbitragem ..., p. 114.

62 MOREIRA NETO, Diogo de Figueiredo. A arbitragem ..., p. 85. 
e direitos não poderão constituir-se em objeto de acordos ou contratos administrativos que visem a sua total disposição. ${ }^{63}$

E aqui está o ponto crucial da problemática que envolve o tema da arbitragem nos contratos firmados pela Administração pública. Cumpre, acima de tudo, indagar-se sobre quais interesses, bens e direitos são passíveis de serem objeto de uma negociação, de um contrato firmado pela Administração. Havendo vedação legal para a negociação ou para a contratação, acordos ou contratos eventualmente firmados a despeito dessa proibição serão nulos de pleno direito.

Por isso não há que cogitar-se de transação, e muito menos de arbitragem (a qual não prescinde de uma prévia relação jurídica contratual) nos casos em que o ordenamento prive a Administação de dispor sobre interesses, bens e direitos.

Apreciando a transação e sua admissibilidade no direito público, Allan $\mathbf{R}$. BREWER-CARIAS aduz que por meio dela são realizados sacrifícios, renúncias e disposições (ainda que parciais) sobre as pretensões das partes, ou seja, reciprocas concessōes. $^{64}$

Segundo o autor, haveria hipóteses em que não seria permitido à Administração pública transigir. Aduz que "nas transações celebradas, um ente público não pode renunciar nem afastar as normas de ordem pública", ${ }^{65}$ como é o caso daquelas que fixam ou atribuem competências de caráter fiscal, ou seja, referentes à gestão econômico-financeira ou econômico-fiscal do Estado. Também as competências vinculadas dos órgãos e entidades administrativas — as quais traduzem uma competência obrigatória para a ação administrativa - não podem ser objeto de transação. ${ }^{66}$ Conclui Allan R. BREWER-CARIAS que, embora a possibilidade de transação seja mais reduzida em matéria de direito público, ela somente poderá ter lugar "em relação ao exercício de faculdades discricionais da Administração - as quais dependem de sua livre apreciação da opotunidade e conveniência - e nunca em relação ao exercício de faculdades vinculadas, regradas ou obrigatórias" ${ }^{67}$

Assim, concorda-se com Caio TÁCITO, para quem não devem ser afastados os benefícios da transação "quando a natureza da obrigação de conteúdo mercantil, a ser cumprida pelo órgão público, possibilita que ao acordo de vontade, fruto do vínculo bilateral, possa igualmente suceder o procedimento amigável como dirimente de eventual discrepância no entendimento da latitude da obrigação do administrador". 68

63 Mas há hipóteses legais que autorizam cessōes e permissð̃es de uso de bens públicos, que constituem atos administrativos negociais, e não contratos administrativos, regulados pelo Decreto-lei $n, 9.760 / 46$ e pela Lei federal n. 9.636/98.

64 BREWER-CARIAS, Allan R. Contratos administrativos. Caracas: Editorial Juridica Venezolana, 1992. p. 266.

65 Ibid., p. 268.

66 Id.

67 Ibid., p. 269.

68 TÁCITO, Caio, Arbitragem .... p. 115. 
Carlos E. DELPIAZZO defende que a admissão da arbitragem não implica comprometer o interesse público, nem em sua superioridade frente aos interesses particulares, nem em relação a sua indisponibilidade. Para o autor, "pactuar a cláusula compromissória não significa contrariar o interesse público quando ordenamento, implícita ou explicitamente, atribui competência a uma entidade pública para firmar tal compromisso". ${ }^{69}$

Assim, a indisponibilidade do interesse público há de ser assimilada nos termos acima apresentados, o que permite firmar entendimento favorável à arbitragem (e à transação) em matéria administrativa.

Aliás, insta fazer menção a dois importantes precedentes do Supremo Tribunal Federal. O primeiro é conhecido como caso $L A G E$, em que o Excelso Pretório firmou entendimento segundo o qual seria possível à União firmar compromisso arbitral. ${ }^{70}$ Outro julgado, bem mais recente que o anterior, refere-se ao litígio envolvendo sentença homologatória de transação celebrada entre um Município e servidores municipais, o Excelso Pretório decidiu que "há casos em que o princípio da indisponibilidade do interesse público deve ser atenuado, mormente quando se tem em vista que a solução adotada pela Administração é a que melhor atenderá à ultimação deste interesse". 71

Inclusive, não podem ser desprezados os casos em que a legislação reconhece a possibilidade de serem realizados acordos ou transações para a resolução de litígios judiciais envolvendo interesses dos entes políticos e administrativos. A Lei federal n. 9.469/97, à guisa de exemplo, faculta ao Advogado-Geral da União e os dirigentes máximos das autarquias, das fundações e das empresas pública federais autorizar tais acordos e transações nas causas de valor até $\mathrm{R} \$ 50.000,00$ (cinquenta mil reais), abrindo espaço (embora com condiçðes especificas) para estender tal possibilidade a causas que versem sobre valores superiores ao assinalado.

Firmado entendimento favorável à arbitragem em matéria administrativa, passa-se à conciliação do instituto com os contratos firmados pela Administração, com especial enfoque nas legislações estaduais especificas sobre as PPPs, apresentando de que modo o tema da arbitragem foi recepcionado e desenvolvido por tais diplomas normativos.

\section{Conciliando a arbitragem com as parcerias público-privadas}

No campo das relações do MERCOSUL, do art. 18 do Protocolo de Las Leñas (no qual os Estados comprometem-se a prestar assistência mútua e ampla cooperação jurisdicional em matéria civil, comercial trabalhista e administrativa) depreende-se

69 DELPIAZZO, Carlos E. El arbitraje en la contratación administrativa en el ámbito del Mersosur. Revista de Direito Administrativo \& Constitucional, Curitiba, n. 4, p. 33-44, 2000. p. 38.

70 Supremo Tribunal Federal, Agravo de Instrumento n. 52.181, Rel. Min. Bilac PINTO, j. em 14.11.1973 (RTJ 68/382).

71 Supremo Tribunal Federal, Recurso Extraordinário n. 253.885-0, Rel. Min. Ellen GRACIE, j. em 04.06.2002 (DJU 21.06.2002). 
o reconhecimento (ou ao menos a possibilidade) de que sentenças e laudos arbitrais pronunciados nas jurisdições dos Estados partes podem ter por objeto matéria administrativa. ${ }^{72}$

Com efeito, a partir das âncoras lançadas nos itens precedentes, parece não existir dúvidas sobre a possibilidade do recurso à arbitragem para a solução de litígios envolvendo relações contratuais das quais a Administração seja parte. E a legislação parece sinalizar nesse sentido.

A Lei federal n. 10.433/02 explicitamente estipula que os agentes integrantes do Mercado Atacadista de Energia Elétrica-MAE - entidade privada, sem fins lucrativos constituída com a finalidade de viabilizar as transações de compra e venda de energia elétrica nos sitemas interligados - poderão socorrer-se do juízo arbitral para a solução de divergências acerca de direitos relativos a créditos e débitos decorrentes das operações realizadas nesse âmbito (qualificados como direitos disponíveis; par. $5^{\circ}$ do art. $2^{\circ}$ ). $\mathrm{O}$ par. $4^{\circ}$ do art. $2^{\circ}$ dessa lei autoriza as empresas públicas e sociedades de economia mista, suas subsidiárias ou controladas, titulares de concessão, permissão e autorização a aderir ao MAE e utilizar-se da convenção de arbitragem referida no parágrafo antecedente do mesmo artigo da lei.

Embora admitindo o emprego do juízo arbitral em matéria de contratos administrativos, maciço número de doutrinadores entende ser absolutamente necessário haver uma expressa autorização legislativa para a submissão das controvérsias de cunho contratual a essa espécie alternativa de solução de conflitos. Tal entendimento é assumido em vista da exigência legal, como cláusula necessária dos contratos administrativos (mesmo aqueles de feição privada), da previsão de que o foro competente para dirimir qualquer questão contratual será - salvo o disposto no par. $6^{\circ}$ da Lei federal n. $8.666 / 93$ - o foro da sede da Administração ( $\S 2^{\circ}$ do art. 55 , c/c par. $3^{\circ}$ do art. 62 , todos da Lei federal n. 8.666/93).

Por outro lado, há entendimento jurisprudencial favorável à arbitragem — não exigindo, portanto, previsão expressão de autorização nesse sentido - baseado em interpretação do art. 54 da Lei federal n. 8.666/93, que determina a aplicação supletiva dos princípios da teoria geral dos contratos e as disposições de direito privado aos contratos administrativos. ${ }^{73} \mathrm{E}$ no caso dos contratos submetidos ao regramento especial da Lei federal n. 8.987/95, o inc. XV do art. 23 ("...modo amigável de solução das divergências contratuais" como cláusula necessária) abriria campo para a utilização da arbitragem.

No entanto, sustenta-se nesse trabalho não haver obrigatoriedade de expressa autorização legal para a utilização do juizo arbitral pela Administração.

Em primeiro lugar, a Lei de Arbitragem é uma lei geral, e não diz respeito a contratos privados ou a contratos públicos, pois dispõe em seu art. $1^{\circ}$ que "as pessoas

72 Sobre MERSOCUL e direito comunitário, cf. BACELLAR FILHO, Romeu Felipe. O Mercosul e a importância do direito comunitário emergente. Revista de Direito Administrativo. Rio de Janeiro, n. 210, p. 117-122, out./dez. 1997.

73 Tribunal de Justiça do Distrito Federal, Mandado de Segurança n. 1998002 003066-9, Rel. Des. Nancy ANDRIGHI, j. em 18.05.1999. 
capazes de contratar poderão valer-se da arbitragem para dirimir litígios relativos a direitos patrimoniais disponíveis". Assim, comprovada a capacidade de contratar e a disponibilidade dos direitos patrimoniais, aberta estará a porta para a utilização da via arbitral. Isso afastaria argumentos que procuram atrair para o campo da arbitragem tão-somente os contratos firmados pelas empresas estatais, sob o fundamento de que o inc. III do par. $1^{\circ}$ do art. 173 da Lei Maior determina "a sujeição ao regime jurídico próprio das empresas privadas ...". Tais argumentos partem de premissa equivocada, pois consideram a arbitragem um mecanismo típico de solução de controvérsias que envolvem interesses eminentemente privados, e por isso devem ser afastados.

Em segundo lugar, o que realmente deve ser apreciado nessa temática é a natureza dos interesses, bens e direitos relativos ao contrato firmado pela Administração. Permitida a sua configuração como objeto de contrato a ser firmado pela Administração - objeto lícito e possível, reitere-se - haverá espaço para a eleição do juízo arbitral. Questões envolvendo a Administração como locatária, adquirente de bens e serviços em geral, ou seja, contratos de nítida feição privatística, podem prever em seus instrumentos a convenção arbitral. $O$ que deve ser apreciado é a ocorrência ou não de vedação legal, como acontece no art. 59 do Decreto-lei n. 960/38, o qual estipula que "a cobrança judicial da dívida ativa da Fazenda não poderá ser submetida a juízo arbitral". Ou a referente ao par. $2^{\circ}$ do art. $1^{\circ}$ da Lei federal n. 9.469/97, que afasta a possibilidade de transação judicial nas causas relativas ao patrimônio imobiliário da União.

Em terceiro lugar, prever-se legislativamente a competência do foro da sede da Administração como aquele que irá dirimir as controvérsias relativas ao contrato não significa a obrigatoriedade de submissão desses litígios unicamente ao Poder Judiciário, pois em verdade trata-se de uma questão de foro de eleição ou foro contratual. Concorda-se com Carlos Alberto CARMONA, para quem "elegendo as partes foro no contrato (...) estarão apenas determinando que o eventual concurso do juiz togado para a realização de atos para os quais o árbitro não tenham competência (atos que impliquem a utilização de coerção, execução da sentença arbitral, execução de medidas cautelares) sejam realizados na comarca escolhida". ${ }^{74}$

Em quarto lugar, a arbitragem não é um método amigável de solução de litígios, e sim, notadamente diante do art. 31 da $\mathrm{LA}^{75}$ uma solução criada pelo legislador como alternativa à solução jurisdicional, e por ele equiparada a esta. Por isso, a rigor o inc. XV do art. 23 da Lei federal n. 8.987/95 não refere-se à arbitragem quando alude à "modo amigável de solução das divergências contratuais". Isso reforça a tese aqui defendida, de que não há necessidade de expressa (ainda que genérica) autorização legislativa para a arbitragem ser uma possibilidade nos contratos admi-

74 CARMONA, Carlos Alberto. Op. cit., p. 64-65. No mesmo sentido, WALD, Arnoldo et al. $O$ direito de parceria e a lei de concessões. 2. ed. São Paulo: Saraiva, 2004. p. 374.

75 "A sentença arbitral produz entre as partes e seus sucessores, os mesmos efeitos da sentença proferida pelos órgãos do Poder Judiciário e, sendo condenatória, constitui título executivo". Cf. CARMONA, Carlos Alberto. Op. cit., p. 45. 
nistrativos. Essa autorização é geral, e, conforme foi ressaltado, encontra-se no art. $1^{\circ}$ da LA.

No entanto, cabem ainda algumas considerações voltadas à necessidade de compatibilização do procedimento arbitral previsto na LA às peculiaridades dos contratos firmados pela Administração.

Em primeiro lugar, a possibilidade de as partes optarem pela via arbitral há de estar prevista explicitamente no Edital de Licitação, e obedecer rigorosamente o previsto no par. $2^{\circ}$ do art. $4^{\circ}$ da LA, pois os contratos administrativos são autênticos contratos de adesão.

Em segundo lugar, jamais um pacto de arbitragem firmado pela Administração poderá expressar preferência ou opção por critérios alternativos ao critério de direito. Os contratos administrativos regem-se pela legislação especial que os disciplina, não podendo haver decisões tomadas com base na equidade, por exemplo, ou quaisquer outros critérios previstos no art. $2^{\circ}$ da LA (além do critério do direito), o que afrontaria 0 art. 37 da Constituição da República.

Em terceiro lugar (embora tal princípio ou atributo não conste expressamente na LA), do par. $6^{\circ}$ do art. 13 da LA pode-se inferir que o procedimento arbitral deverá desenvolver-se em caráter de sigilo ou confidencialidade entre as partes. Ora, em face do princípio da publicidade previsto em sede constitucional, não é admitido qualquer forma de segredo no trato dos assuntos públicos. A exceção residiria nos contratos denominados sigilosos, nos termos da Lei federal n. 8.159/91 e dos artigos 59 e 60 do Decreto n. 4.553/02. Aliás, aqui poderia ser incentivada a possibilidade da utilização do juízo arbitral para a solução de litígios que envolvam esses contratos, pois em jogo estariam informações e dados cujo conhecimento irrestrito ou divulgação poderiam acarretar risco à segurança da sociedade e do Estado.

Em face do exposto, inclina-se para a necessidade de serem realizados ajustes na Lei de Arbitragem, com relação às controvérsias que digam respeito a contratos administrativos. Na própria Lei de Arbitragem poderia ser previsto um procedimento especial de arbitragem, quando os litígios a serem submetidos ao juízo arbitral envolvessem objetos típicos de contratos firmados pela Administração.

Finalmente, em relação à nova contratualização administrativa, diante das peculiaridades apontadas no itens 1,2 e 3 supra - mormente a ampliação das bases de negociação e de um maior equilíbrio entre as posições ocupadas pelo parceiro público e pelo parceiro privado - a legislação federal e estadual ora existente sobre as PPPs prevê o recurso ao juízo arbitral para a solução de controvérsias.

Nos termos do art. $2^{\circ}$ da Lei federal n. 11.079/04, "parceria público-privada é o contrato administrativo de concessão, na modalidade patrocinada ou administrativa". A concessão patrocinada é a concessão de serviços públicos ou de obras públicas de que trata a Lei no 8.987, de 13 de fevereiro de 1995, quando envolver, adicionalmente à tarifa cobrada dos usuários contraprestação pecuniária do parceiro público ao parceiro privado $\left(\S 1^{\circ} \mathrm{do}\right.$ art. $\left.2^{\circ}\right)$. De outro lado, concessão administrativa é o contrato de prestação de serviços de que a Administração Pública seja a usuária direta ou indireta, ainda que envolva execução de obra ou fornecimento e instalação de bens $\left(\xi 2^{\circ}\right.$ do art. $\left.2^{\circ}\right)$. 
Segundo o art. $4^{\circ}$ da Lei federal n. 11.079/04, "na contratação de parceria público-privada serão observadas as seguintes diretrizes: I - eficiência no cumprimento das missões de Estado e no emprego dos recursos da sociedade; II - respeito aos interesses e direitos dos destinatários dos serviços e dos entes privados incumbidos da sua execução; III - indelegabilidade das funções de regulação, jurisdicional, do exercício do poder de polícia e de outras atividades exclusivas do Estado; IV responsabilidade fiscal na celebração e execução das parcerias; $V$ - transparência dos procedimentos e das decisões; VI - repartição objetiva de riscos entre as partes; VII - sustentabilidade financeira e vantagens socioeconômicas dos projetos de parceria".

Por seu turno, o art. $5^{\circ}$ da Lei federal n. 11.079/04 dispõe que "as cláusulas dos contratos de parceria público-privada atenderão ao disposto no art. 23 da Lei no 8.987, de 13 de fevereiro de 1995, no que couber, devendo também prever: I - o prazo de vigência do contrato, compatível com a amortização dos investimentos realizados, não inferior a 5 (cinco), nem superior a 35 (trinta e cinco) anos, incluindo eventual prorrogação; II - as penalidades aplicáveis à Administração Pública e ao parceiro privado em caso de inadimplemento contratual, fixadas sempre de forma proporcional à gravidade da falta cometida, e às obrigações assumidas; III - a repartição de riscos entre as partes, inclusive os referentes a caso fortuito, força maior, fato do príncipe e álea econômica extraordinária; IV - as formas de remuneração e de atualização dos valores contratuais; $\mathrm{V}$ - os mecanismos para a preservação da atualidade da prestação dos serviços; VI - os fatos que caracterizem a inadimplência pecuniária do parceiro público, os modos e o prazo de regularização e, quando houver, a forma de acionamento da garantia; VII - os critérios objetivos de avaliação do desempenho do parceiro privado; VIII - a prestação, pelo parceiro privado, de garantias de execução suficientes e compatíveis com os ônus e riscos envolvidos, observados os limites dos $\S \S 3^{\circ}$ e $5^{\circ}$ do art. 56 da Lei no 8.666 , de 21 de junho de 1993, e, no que se refere às concessões patrocinadas, o disposto no inciso XV do art. 18 da Lei $n^{\circ} 8.987$, de 13 de fevereiro de 1995; IX - o compartilhamento com a Administração Pública de ganhos econômicos efetivos do parceiro privado decorrentes da redução do risco de crédito dos financiamentos utilizados pelo parceiro privado; $\mathrm{X}$ - a realização de vistoria dos bens reversíveis, podendo o parceiro público reter os pagamentos ao parceiro privado, no valor necessário para reparar as irregularidades eventualmente detectadas".

Especialmente no que diz respeito à arbitragem, a Lei federal n. 11.079/04 estipula em seu art. 11:

Art. 11. O instrumento convocatório conterá minuta do contrato, indicará expressamente a submissão da licitação às normas desta Lei e observará, no que couber, os $\S \S 3^{\circ}$ e $4^{\circ}$ do art. 15 , os arts. 18,19 e 21 da Lei ${ }^{\circ} 8.987$, de 13 de fevereiro de 1995 , podendo ainda prever:

I - exigência de garantia de proposta do licitante, observado o limite do inciso III do art. 31 da Lei $n^{\circ} 8.666$, de 21 de junho de 1993; 


\section{II - (VETADO)}

III - o emprego dos mecanismos privados de resolução de disputas, inclusive a arbitragem, a ser realizada no Brasil e em língua portuguesa, nos termos da Lei $n^{\circ}$ 9.307, de 23 de setembro de 1996, para dirimir conflitos decorrentes ou relacionados ao contrato. (sem grifo no original)

\section{A Lei Mineira de PPP estabelece:}

Art. 13 - Os instrumentos de parceria público-privada previstos no art. 11 desta Lei poderão estabelecer mecanismos amigáveis de solução de divergências contratuais, inclusive por meio de arbitragem.

$\S 1^{\circ}$ - Na hipótese de arbitragem, os árbitros serão escolhidos dentre pessoas naturais de reconhecida idoneidade e conhecimento da matéria, devendo o procedimento ser realizado de conformidade com regras de arbitragem de órgão arbitral institucional ou entidade especializada.

$\S 2^{\circ}$ - A arbitragem terá lugar na Capital do Estado, em cujo foro serão ajuizadas, se for o caso, as ações necessárias para assegurar a sua realização e a execução da sentença arbitral.

Por sua vez, a Lei Catarinense estipula na alínea (e) do inciso IIII do artigo 10 que "a contratação de parceria público-privada deve ser precedida de licitação na modalidade de concorrência, observado o seguinte: (...) III - no edital de licitação, poderá se exigir: (e) facultar a adoção da arbitragem para solução dos conflitos decorrentes da execução do contrato".

Na Lei Paulista consta que "os instrumentos de parcerias publico-privadas poderão prever mecanismos amigáveis de solução das divergências contratuais, inclusive por meio de arbitragem, nos termos da legislação em vigor" (art. 11).

Por seu turno, o artigo 15 da Lei Goiana determina que "os instrumentos de parcerias público-privadas poderão prever, nos termos da legislação em vigor, mecanismos amigáveis de solução das divergências contratuais, inclusive por meio de arbitragem, na qual os árbitros deverão ser escolhidos dentre os vinculados as instituições especializadas na matéria e de reconhecida idoneidade". O par. único desse artigo estipula que "a arbitragem terá lugar na Capital do Estado, em cujo foro serão ajuizadas, se for o caso, as ações necessárias para assegurar a sua realização e execução da sentença arbitral".

\section{Considerações finais}

A expansão do consensualismo na Administração pública vem acarretando a restrição de medidas de cunho unilateral e impositivo a determinadas áreas da ação administrativa. Isso provoca o florescimento da denominada Administração consen- 
sual, e a mudança de eixo do direito administrativo, que passa a ser orientado pela lógica da autoridade permanentemente flexionada pela lógica do consenso.

Ato administrativo e contrato administrativo, portanto, são encarados como formas jurídicas adotadas pela Administração pública para a consecução de suas tarefas, e passam a ser regidos por uma lógica similar, mais voltada à busca do consenso.

De outro lado, a aproximação do regime de direito público e do regime de direito privado, apontada como uma linha de transformação do direito administrativo contemporâneo, surte efeitos na tratativa principiológica, dogmática e legislativa correspondente aos contratos firmados pela Administração pública, suscitando a reavaliação dos institutos e procedimentos existentes.

Tais mudanças levam à reformulação da tradicional abordagem dos procedimentos pré-negociais e negociais observados pela Administração, com maior abertura para o diálogo acerca das cláusulas que irão reger a relação jurídica a ser instaurada pela via do ajuste.

Em franco desenvolvimento encontra-se a nova contratualização administrati$v a$, a qual desenvolve-se em bases negociais mais amplas se comparadas aos modelos contratuais tradicionais, parecendo sinalizar (i) para uma maior paridade entre Administração e particular e (ii) uma reforçada interdependência entre as prestações a cargo de ambas as partes. Daí aludir-se à expressão Administração pública paritária, para caracterizar uma forma de administrar fundada no consenso, em módulos negociais, originando relações jurídicas que tendem a considerar Administração e particulares em uma situação mais próxima à horizontalidade, em que o ordenamento confere a ambos um tratamento mais isonômico.

Mesmo nos contratos qualificados como tradicionais, essas transformações podem ser visualizadas. Exemplificando, a inoponibilidade da exceção do contrato não cumprido em sede de contratos administrativos vem sofrendo abrandamentos em seu significado e extensão, levando autores como Romeu Felipe BACELLAR FILHO a afirmar que "mesmo a continuidade do serviço público não poderia justificar a ruína do particular; valendo a aplicação da exceptio non adimpleti contractus sempre que se caracterize, no caso concreto, situação de (razoável) impedimento da execução contratual pelo particular, detectado com base num juízo de razoabilidade radicado no valor justiça". ${ }^{76}$

No que tange à arbitragem, aliada à superação dos argumentos desfavoráveis comumente arrolados, encontra-se o fato de que o aparecimento de novas formas de contratualização administrativa vem produzindo câmbios acentuados nos entendimentos até então arraigados na doutrina e na jurisprudência, que procuravam afastar a utilização do juízo arbitral para o deslinde de controvérsias envolvendo contratos administrativos.

76 BACELlaR FILHO, Romeu Felipe. Contrato ..., p. 320. No mesmo sentido, MEDAUAR, Odete. $O$ direito administrativo .... p. 209. 
As PPPs encaixam-se nessa nova fase da contratualização administrativa, e o novel arsenal legislativo a elas correpondentes deve refletir o desenvolvimento da atividade negocial administrativa, com a admissão do juízo arbitral para a solução dos litígios relacionados à relação jurídica instaurada entre o parceiro público e o parceiro privado.

Entretanto, diante das especificidades inerentes ao objeto público das PPPs, há a necessidade de serem realizados ajustes na atual legislação brasileira da arbitragem, com a criação de um procedimento arbitral especial, necessário para conferir maior proteção aos interesses da coletividade presentes nessa especial relação de natureza contratual.

\section{Bibliografia}

AICARDI, Nicola. La disciplina generale e i principi degli accordi amministrativi: fondamento e caratteri. Rivista trimestrale di diritto pubblico, Roma, a. 47, n. 1, p. $1-59,1997$.

ALBERTI, Piergiorgio et al. (org.). Lezioni sul procedimento amministrativo. 2. ed. Torino: G. Giappichelli, 1995.

ÁNGEL BERÇAITZ, Miguel. Teoría general de los contratos administrativos. 2. ed. Buenos Aires: Depalma, 1980.

ARIÑO ORTIZ, Gaspar. El retorno a lo privado: ante una nueva encrucijada histórica. tiempo. In: (Org.). Privatización y liberalización de servicios. Madrid: Universidad Autónoma de Madrid, 1999. p. 19-35.

BACELLAR FILHO, Romeu Felipe. Contrato administrativo. In: et al (Coord.). Direito administrativo contemporâneo: estudos em memória ao Professor Manoel de Oliveira Franco Sobrinho. Belo Horizonte: Fórum, 2004. p. 307-326.

BACELLAR FILHO, Romeu Felipe. O Mercosul e a importância do direito comunitário emergente. Revista de Direito Administrativo, Rio de Janeiro, n. 210, p. 117-122, out./dez. 1997.

BACELLAR FILHO, Romeu Felipe. Princípios constitucionais do processo administrativo disciplinar. 2. ed. São Paulo: Max Limonad, 2003.

BANDEIRA DE MELLO, Celso Antônio. Curso de direito administrativo. 15. ed. São Paulo: Malheiros, 2003.

BARBAGALLO, Giuseppe et al. (org.) Gli accordi fra privati e pubblica amministrazione e la disciplina generale del contrato. Napoli: Edizioni Scientifiche Italiane, 1995.

BARBOSA, Joaquim Simões; SOUZA, Carlos Affonso Pereira de. Arbitragem nos contratos administrativos: panorama de uma discussão a ser resolvida. In: ALMEIDA, Ricardo Ramalho. Arbitragem interna e internacional: questões de doutrina e prática. Rio de Janeiro: Renovar, 2003. p. 267-291.

BOBBIO, Norberto. A via democrática. In: . As ideologias e o poder em crise. 4. ed. Brasília: Editora Universidade de Brasília, 1999. p. 160-164. 
BREWER-CARIAS, Allan R. Contratos administrativos. Caracas: Editorial Jurídica Venezolana, 1992.

CARMONA, Carlos Alberto. Arbitragem e processo: um comentário à lei $n$. 9.307/96. 2. ed. São Paulo: Atlas, 2004.

CASSESE, Sabino. La arena pública: nuevos paradigmas para el Estado. In: La crisis del Estado. Buenos Aires: Abeledo Perrot, 2003. p. 101-160.

CASSESE, Sabino. Las bases del derecho administrativo. Madrid: Instituto Nacional de Administración Pública, 1994.

CORREIA, José Manuel Sérvulo. Legalidade e autonomia contratual nos contratos administrativos. Coimbra: Almedina, 1987.

COUTO E SILVA, Almiro. Os indivíduos e o Estado na realização de tarefas públicas. Revista de direito administrativo, Rio de Janeiro, v. 209, p. 43-70, jul./set. 1997.

DALlARI, Adilson Abreu. Arbitragem na concessão de serviço público. Revista de Informação Legislativa, Brasília, a. 32, n. 128, p. 63-67, out./dez. 1995.

DAMIANI, Ernesto Sticchi. Attività amministrativa consensuale e accordi di programma. Milano: Giuffrè, 1992.

DELPIAZZO, Carlos E. El arbitraje en la contratación administrativa en el ámbito del Mersosur. Revista de Direito Administrativo \& Constitucional, Curitiba, n. 4, p. 33-44, 2000.

DI PIETRO, Maria Sylvia Zanella. Parcerias na administração pública: concessão, permissão, franquia, terceirização e outras formas. 4. ed. São Paulo: Atlas, 2002.

ESCOLA, Héctor Jorge. El interés público como fundamento del derecho administrativo. Buenos Aires: Depalma, 1989.

ESTORNINHO, Maria João. A fuga para o direito privado. Coimbra: Almedina, 1996.

ESTORNINHO, Maria João. Requiem pelo contrato administrativo. Coimbra: Almedina, 1990.

FAGUNDES, Maria Aparecida de Almeida Pinto S. Parcerias em projetos de infraestrutura. Revista de Direito Administrativo, Rio de Janeiro, n. 233, p. 419-429, jul./set. 2003.

FERNÁNDEZ, Tomás-Ramón, GARCÍA DE ENTERRÍA, Eduardo. Curso de derecho administrativo. 9. ed. Madrid: Civitas, 1999, v. 1.

FERNÁNDEZ, Tomás-Ramón; GARCÍA DE ENTERRÍA, Eduardo. Curso de derecho administrativo. 6. ed. Madrid: Civitas, 1999, v. 2.

GARCIA, Ailton Stropa. A arbitragem no direito econômico nacional e internacional. Revista de Direito Constitucional e Internacional, São Paulo, a. 8, n. 33, p. 28-45, out./dez. 2000.

GAUDIN, Jean-Pierre. Gouverner par contrat: l'action publique en question. Paris: Presses de Sciences Politiques, 1999.

GIANNINI, Massimo Severo. Premisas sociológicas e históricas del derecho administrativo. Madrid: Instituto Nacional de Administración Pública, 1987.

GIDDENS, Anthony. A terceira via. Rio de Janeiro: Record, 2000.

GONÇALVES, Pedro. O contrato administrativo. Coimbra: Almedina, 2003. 
GRAU, Eros Roberto. Arbitragem e contrato administrativo. Revista Trimestral de Direito Público, São Paulo, n. 32, p. 14-20, 2000.

GRINOVER, Ada Pellegrini. Arbitragem e prestação de serviços públicos. Revista de Direito Administrativo, Rio de Janeiro, n. 233, p. 377-385, jul./set. 2003.

GUERREIRO, José Alexandre Tavares. Arbitragem nos contratos com o Estado: direito brasileiro e direito comparado. SEMINÁRIO INTERNACIONAL SOBRE DIREITO ARBITRAL. 1., 2003, Belo Horizonte [Trabalhos apresentados], Belo Horizonte: Câmara de Arbitragem de Minas Gerais, 2003. p. 294-304.

JUSTEN FILHO, Marçal. As diversas configurações da concessão de serviço público. Revista de direito público da economia, Belo Horizonte, a.1, n. 1, p. 95-136. jan./mar. 2003.

JUSTEN FILHO, Marçal. Conceito de interesse público e a "personalização" do direito administrativo. Revista Trimestral de Direito Público, São Paulo, n. 26, p. $115-136,1999$.

JUSTEN FILHO, Marçal. Teoria geral das concessões de serviço público. São Paulo: Dialética, 2003.

LAUBADÈRE, André et al. Traité des contrats administratifs. Paris: L.G.D.J., 1983. v. 1.

LAUBADÈRE, André. Administration et contrat. In: LAUBADÈRE, André et al. Pages de doctrine. Paris: L. G. D. J., 1980. v. 2, p. 239-252.

LIMA, Cláudio Vianna de. A lei de arbitragem e o art. 23, XV da Lei de Concessões. Revista de Direito Administrativo, Rio de Janeiro, n. 209, p. 91-104, jul./set. 1997.

LOPES, Carlos Thomas G. Planejamento, estado e crescimento. São Paulo: Pioneira, 1989.

MASUCCI, Alfonso. Trasformazione dell'amministrazione e moduli convenzionali: il contratto di diritto pubblico. Napoli: Jovene, 1988.

MATTOS, Mauro Roberto Gomes. Contrato administrativo e a lei de arbitragem. Revista de Direito Administrativo, Rio de Janeiro, n. 223, p. 115-131, jan./mar. 2001.

MEDAUAR, Odete. $O$ direito administrativo em evolução. 2. ed. São Paulo: RT, 2003.

MEDEIROS, Suzana Domingues. Arbitragem envolvendo o Estado no direito brasileiro. Revista de Direito Administrativo, Rio de Janeiro, n. 233, p. 71-101, jul./set. 2003.

MOREIRA NETO, Diogo de Figueiredo. Arbitragem nos contratos administrativos. Revista de Direito Administrativo, Rio de Janeiro, n. 209, p. 81-90, jul./set. 1997.

MOREIRA NETO, Diogo de Figueiredo. Novos institutos consensuais da ação administrativa. Revista de Direito Administrativo, Rio de Janeiro, v. 231, p. 129-156, jan./mar. 2003.

MOREIRA, Vital. Organização Administrativa. Coimbra: Coimbra Editora, 2001. MOTTA, Carlos Pinto Coelho. Arbitragem nos contratos administrativos. Boletim de Direito Administrativo, São Paulo, v. 13, n. 10, p. 672-676, out. 1997. 
NABAIS, José Casalta. Contratos fiscais: reflexões acerca da sua admissibilidade. Coimbra: Coimbra, 1994.

NAMBLARD, Corinne. Para um enfoque pragmático da parceria público-privado. In: CHATELUS, Gautier; PERROT, Jean-Yves (Dir.) Financiamento das infraestruturas e dos serviços coletivos: o recurso à parceria público-privado: os exemplos da experiência francesa no mundo. Paris: DAEI, 1994. p. 13-28.

PALMA DEL TESO, Ángeles de. Los acuerdos procedimentales en el derecho administrativo. Valencia: Tirant lo blanch, 2000.

PATRIKIOS, Apostolos. L'arbitrage en matière administrative. Paris: L.G.D.J., 1997.

RIVERO ORTEGA, Ricardo. Administraciones públicas y derecho privado. Madrid: Marcial Pons, 1998.

RIVERO ORTEGA, Ricardo. Repensando el estado de derecho: el arbitraje administrativo como alternativa al colapso jurisdiccional en el control de la Administración. In: SOSA WAGNER, Francisco (coord.) El derecho administrativo en el umbral del siglo XXI: homenage al Profesor Dr. D. Ramón Martín Mateo, Valencia: Tirant lo Blanch, 2000. t. 1, p. 2487-2497.

RODRÍGUEZ DE SANTIAGO, José Maria. Los convenios entre administraciones públicas. Madrid: Marcial Pons, 1997.

ROPPO, Enzo. $O$ contrato. Coimbra: Almedina, 1988.

SOTO KLOSS, Eduardo. La contratacion administrativa: um retorno a las fuentes classicas del contrato. Revista de administración publica, Madrid, n. 2, p. 569$585,1978$.

SZKLAROWSKY, Leon Frejda. Arbitragem e os contratos administrativos. Revista de Direito Administrativo, Rio de Janeiro, n. 209, p. 105-107, jul./set. 1997.

TÁCITO, Caio. Arbitragem nos litígios administrativos. Revista de Direito Administrativo, Rio de Janeiro, n. 210, p. 111-115, out./dez. 1997.

TIBURCIO, Carmen. A lei de arbitragem e a pretensa inconstitucionalidade de seu artigo $7^{\circ}$. Revista de Direito Administrativo, Rio de Janeiro, n. 218, p. 175-196, out./dez. 1999.

WALD, Arnoldo et al. $O$ direito de parceria e a lei de concessões. 2. ed. São Paulo: Saraiva, 2004. 


\section{Elementos de Direito Urbanístico}

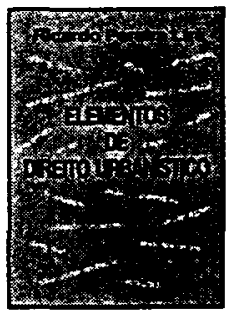

\section{Ricardo Pereira Lira}

Ref. 0147

Brochura

400 págs.

Form. $14 \times 21$

1997

ISBN 85-7147-057-X

Esta coletânea de textos sobre Direito Urbanístico oferece o leque das perspectivas do ordenamento jurídico brasileiro desde as origens coloniais até o tratamento na vigente Constituição. Entre os temas enfrentados com brilhantismo pelo autor, Protessor Titular de Direito Civil da Universidade do Estado do Rio de Janeiro, estão o Direito de Superfície, a utilização compulsória do solo, a concessão do direito real de uso e o planejamento urbano.

\section{Evoluçāo da Responsabilidade Civil e Reparação de Danos Ambientais}

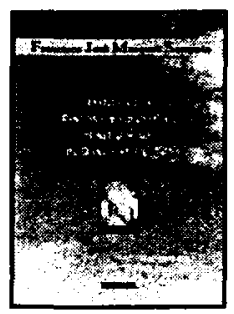

Francisco José Marques Sampaio

Ref. 0440

Brochura

300 págs.

Form. $14 \times 21$

2003

ISBN 85-7147-313-7

Livro dedicado à reparação de danos ao meio ambiente. São apresentados fundamentos de ordens ética e jurídica para justificar a utilização de presunções de danos ambientais como meio de propiciar sua reparação em situaf̧ões nas quais a prova de suas ocorrências se revelar especialmente complexa ou difícil. Procede-se, também. a estudo da evolução da responsahilidade civil.

\section{Paradigma Biocêntrico: do Patrimônio Privado ao Patrimônio Ambiental}

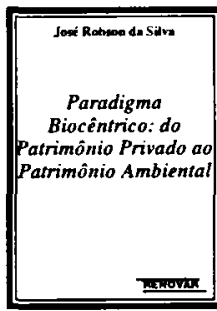

Jose Robson da Silva

Ref. 0401

Brochura

472 págs.

Form. $13,5 \times 21$

2002

ISBN 85-7147-852-X

São examinados o percurso do conceito tradicional de patrimônio à definição coeva das titularidades e a superação do paradigma antropocêntrico, alcançando o tenômeno da repersonalização do Direito Civil. 0 autor funda-se numa hermenêutica crítica e construtiva a partir da CF de 1988, estribando-se nas idéias de Michel Serres para sobrepujar o contrato social por meio de uma ecologia social que privilegie a variedade humana e cultural.

\section{Trânsito}

Como policiar, ser policiado e recorrer das puniçōes

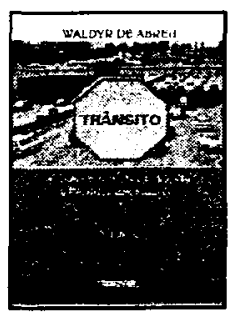

\section{Waldyr de Abreu}

Ref. 0348

Brochura

390 págs.

Form. $14 \times 21$

2001

ISBN 85-7147-295-5

Este livro é uma reedição, estimulada pela promulgação do atual Código, movido por dois alvos principais. 0 primeiro é 0 de contribuir para 0 aperfeiçoamento do policiamento de trânsito. A qualidade deste é que determina os efeitos do Código na via pública, em sentido positivo ou negativo. 0 outro objetivo é o de estimular e ensinar a recorrer a quem seja alcançado por alguma punição administrativa, quando se julgue injustiçado. 